IRA-International Journal of Education \& Multidisciplinary Studies

ISSN 2455-2526; Vol.13, Issue 03 (December, 2018)

Pg. no. 27-40.

Institute of Research Advances

Institute of
Research
Advances

http://research-advances.org/index.php/IJEMS

\title{
Unemployment, Psychological Trauma, Militancy and Boko Haram Conflict in Nigeria
}

\author{
Joyce Mcivir Terwase ${ }^{1}$, Isaac Terungwa Terwase ${ }^{2 \#}$, Gloria Samdi Puldu ${ }^{3}$ \& Asmat- \\ Nizam Abdul-Talib ${ }^{4}$ \\ ${ }^{1}$ Department of Psychology, Benue State University, Makurdi, Nigeria. \\ ${ }^{2}$ Department of Political Science, Coal City University, Enugu, Nigeria. \\ ${ }^{3}$ Department of Political Science, University of Jos, Jos, Nigeria. \\ ${ }^{4}$ School of International Studies, Universiti Utara Malaysia, Sintok, Malaysia.
}

\#corresponding author.

Type of Review: Peer Reviewed.

DOI: http://dx.doi.org/10.21013/jems.v13.n3.p1

\section{How to cite this paper:}

Terwase, J.M., Terwase, I.T., Puldu, G.S., Abdul-Talib, A.N.. (2018). Unemployment, Psychological Trauma, Militancy and Boko Haram Conflict in Nigeria. IRA International Journal of Education and Multidisciplinary Studies (ISSN 2455-2526), 13(3), 27-40.doi: http://dx.doi.org/10.21013/jems.v13.n3.p1

(C) Institute of Research Advances.

This work is licensed under a Creative Commons Attribution-Non Commercial 4.0 International License subject to a proper citation to the publication source of the work.

Disclaimer: The scholarly papers as reviewed and published by the Institute of Research Advances (IRA) are the views and opinions of their respective authors and are not the views or opinions of the IRA. The IRA disclaims of any harm or loss caused due to the published content to any party.

Institute of Research Advances is an institutional publisher member of Publishers Inter Linking Association Inc. (PILA-CrossRef), USA. The institute is an institutional signatory to the Budapest Open Access Initiative, Hungary advocating the open access of scientific and scholarly knowledge. The Institute is a registered content provider under Open Access Initiative Protocol for Metadata Harvesting (OAI-PMH).

The journal is indexed \& included in WorldCat Discovery Service (USA), CrossRef Metadata Search (USA), WorldCat (USA), OCLC (USA), Open J-Gate (India), EZB (Germany) Scilit (Switzerland), Airiti (China), Bielefeld Academic Search Engine (BASE) of Bielefeld University, Germany, PKP Index of Simon Fraser University, Canada. 


\begin{abstract}
The issue of unemployment has bedeviled the development of many countries especially when the youths who are trained in various skills of human endeavor find it difficult in getting job opportunities. This research work has focused on the impact of unemployment with specific attention to Nigeria. The country over the years from 2009 to date witnessed a series of attacks by the Boko Haram terrorist group whose membership mostly are the youths. The main objective of this research is to examine the impact of unemployment as it causes psychological trauma, frustration and aggression thereby resulting to a state of insecurity. The work made use of qualitative research design through the conduct of interviews. The work also made use of other sources such as journal publications and internet sources. The findings drawn from this research reveal that some of the youths who engage in terrorist attacks against the Nigerian state are unemployed while some could be due to poverty and illiteracy. The issues raised could cause psychological trauma to the victims especially those whose relatives lost their lives as well as those who are internally displaced. The work, therefore, recommends a new public policy framework as a strategy in resolving the conflict in order to sustain peace and security of the country.
\end{abstract}

Keywords: Unemployment, Psychological Trauma, Public Policy, Peace and Conflict Resolution

\title{
1. Introduction
}

The work of Maiangwa, Uzodike, Whetho and Onapajo (2012) argues that when the state cannot perform her primary functions, duties and responsibilities of providing security for the citizens, employment opportunities, infrastructure and meeting the demands of the citizens, it could lose her legitimacy before the citizens. This could lead to transference of allegiance to other responsive groups or certain figures who could be leaders of such groups. The work further explained that some of the citizens may even go as far as becoming members of terrorist groups or organizations.

The frustration-aggression theory opined that, where there is a group that shared grievances in relation to marginalization, neglect, abandoned and having a strong sense of group identity, in such political entity or environment, there is tendency that violence may breakout against such sources of grievances (Gurr, 1994; Maiangwa, Uzodike, Whetho and Onapajo, 2012). This view applied to the insecurity situation created by the Boko Haram in the Nigerian state. The opinion here focused on the frustrated youths who joined or are recruited by the Boko Haram due to factors such as unemployment, poverty, illiteracy, such issues causes aggression within those who are affected (Adibe, 2012).

Adibe (2012) further explained that when the affected masses feel frustrated, abandoned, and even feeling alienated, they may find refuge in other groups such as religious groups. Some of them could be manipulated to wage war as insurgents against the state. The work of Maiangwa, Uzodike, Whetho and Onapajo (2012) asserts another dimension of frustration-aggression theory in explaining the fact that, the Boko Haram insurgents are on a vengeance mission considering the fact that their leader was killed by Nigerian security forces in 2009 alongside other members of the group. After the incidence, most of the Boko Haram members in Northern Nigeria have been harboring anger as a result of the extrajudicial killings that took place which became more aggressive against the government of Nigeria. The main objective of this research is to examine the impact of unemployment as it causes psychological trauma, frustration and aggression thereby resulting to a state of insecurity.

\section{Literature Review}

\subsection{Unemployment}

The concept of unemployment has attracted various definitions; however, there seems to be a consensus in all of these. The International Labour Organization (ILO) captures its definition to reflect the 'unemployed' in numerical terms, this definition captures the term as numbers of the economically active population without work but who are available for and seeking work, including individuals who have lost their work and those who have left work voluntarily (World Bank,1998). This definition cuts across countries of the World, however, the applications are what have been found to be problematic depending on the country. Explaining the point further, Obadan, \& Odusola, (2000) assert that published unemployment rates are recorded open unemployment as the attitudes of people largely depends from one country to another. 
One great challenge pointed out on unemployment is that of labour force underestimation, Aigbokhan (1988) captures the fact that in many countries especially Nigeria, individuals below the age of 15 years and those above 55 years who are actively engaged in economic activities are most often not included in labour statistical surveys, which makes international comparison challenging.

Unemployment in the opinion of Falae, (1971) is defined from two perspectives, 'unemployment' or 'underemployment' of labour factor, which according to him excludes many degrees of under-utilization of productive capacity that involves non-labour variables. On the other hand, in the view of Okafor (2011) as regards unemployment in Nigeria, his work connotes that since Nigeria's democracy has been restored, an avenue should be created for people to be represented in government where issues such as employment opportunities be created for the youths in resolving the unemployment question. This question when left unattended to, could have far-reaching implications socially, economically and politically (Alanana, 2003). He further argues that youth unemployment is quite pervasive throughout Nigeria. Youth unemployment is traceable to the 1970's, 80's and 90's and occurring in acceleration percentages $(6.2 \%, 9.8 \%$ and $11.5 \%$ respectively). Therefore, the problem of youth unemployment is not a new phenomenon, so it deserves complete attention since the survival of the Nigerian economy depends largely on this category of people to grow.

\subsection{Trends in Unemployment}

However, corroborating the above assertion, Ajufo, (2013) identifies the devastating impacts of youth unemployment as having resulted to increased militancy, violent crimes, kidnappings, restiveness and socially delinquent behaviours. Sadly, these impacts of unemployment are devastating both to the individual and the society socially, psychologically and economically. In the course of the paper, potential remediation will be looked at as a panacea for youth unemployment.

The problem of unemployment has constituted great challenges to many countries, both developing and developed. In Nigeria specifically, unemployment affects all categories of age groups including in the educational system and geographical entities. A mentioned earlier, there has been a steady rise in statistics. More empirical evidence from the work of Obadan, \& Odusola, (2000) reveal that the unemployment rate increased from $4.3 \%$ in 1976 to $6.4 \%$ in 1980. In spite of this increase, a decline, however, was recorded between 1981 and 1986, which found the rates to be relatively higher than that which was obtained in the 1960's and 1970s.

Salami, (2011) presents a more current picture of the youth unemployment in Nigeria. At the 2006 census, Nigeria's population was presented to be about 140 million people and rated as the most populous country in Africa, a nominal GDP of \$207.11 billion and per capita income of \$1,401which made Nigeria's economy the second largest in Africa. Having presented these impressive figures, he still found just like other literature that youth unemployment has been a major challenge facing the country. Both un- and underemployment are identified as very critical socio-economic problems bedeviling Nigeria in spite of a growing labour force and a concurrent increase in the proportion of youth, so employment growth is inadequate to absorb market entrants. This has therefore greatly predisposed the youth to unemployment. On the other hand, in terms of underemployment, young people also fall victims to this trend, getting jobs of low quality, working long hours for low wages or even deprivation of wages, being engaged in dangerous work or also receiving short-term and/ or informal employment arrangements. All these and inadequate employment situation which has been mentioned have grave consequences on the psyche of these youths/individuals, as well as socio-economic, political and moral consequences (Aiyedogbon \& Ohwofasa 2012).

Consistently, another impact of the inadequate employment situation in Nigeria has been identified 'poverty'. Available statistics reveal the incidence of poverty in Nigeria which has been on the increase since in the 1980s (Aiyedogbon \& Ohwofasa 2012). Reports from the UNDP (2010), between 1980 and 1996, the percentage of those rated 'core poor' was shown to have risen from $6.2 \%$ to $29.3 \%$ and declined to $22.0 \%$ in 2004 . However, Omotola (2008) reported that about $70 \%$ of the population lives in abject poverty which was revealing of the geographical dimension of poverty in Nigeria, all of which has a direct correlation with unemployment and underemployment. Consequently, the issues arising from clear unemployment and inadequate employment situations could be directly and indirectly linked to causing psychological traumas for these individuals.

\subsection{Psychological Trauma}

Impacts of experiences of unemployment and other inadequate employment issues could be those that may overwhelm psychological and biological coping mechanisms. Psychological trauma hence could be viewed as 
experiencing a severe distress as a result of an overwhelming amount of stress that exceeds an individual's ability to cope or integrate the emotions involved with that experience (McCann, \& Pearlman, 2015).

From the angle of Darity \& Goldsmith (1996), unemployment on theoretical grounds is seen to be capable of destroying psychological health, which invariably could hamper personal productivity. This is for the reason that, unemployment can be quite disastrous to one's emotional health. Anxiety, depression, insomnia, etc are some the psychological distress that unemployed individuals could experience all of which could possibly lead to a poor psychological well-being. The Erikson's (1959) life span developmental theory explains that the healthy development of an individual's ego and self-esteem depends on the successful completion of the eight successive stages. The fifth stage being the industry stage proposes that here an individual must have attained a desirable occupational identity, while at "middle age," the individual desires to have fulfilled life goals that have to do with career, family and society obligations, all of which must be completed. Therefore, unemployment or underemployment could likely reduce an individual's sense of worth and psychological well-being.

\subsection{Unemployment, Militancy and Boko Haram Conflict}

The work of Oyefusi (2008) on oil and youths militancy in Nigeria's Niger-Delta reflects the role of unemployment amongst the youths within the region. The conflict within the Niger-Delta region was led by mainly unemployed youths. That shows most of the young people within the region were unemployed (Ibeanu, 2000). Over the years even before the return of Nigeria's democracy in 1999, the country witnessed crisis in the Niger-Delta region which is the oil-producing area of the country. Many scholars have written on how unemployment creates room for youths to engage in militancy and insurgency in Nigeria. The Northern and Southern parts of Nigeria have witnessed both insurgency cases and that of militancy respectively (Salawu, 2010; Oviawe, 2010; Omofonmwan \& Odia, 2009; Ikelegbe, 2006).

In the light of the above, other scholars attribute Nigeria's cases of insecurity in the country as a result of both poverty and unemployment. More so, when people are poor, they tend to be easily used by militant or insurgent groups. To some, as a result of unemployment, they remain poor and are willing to be used by any group in causing havoc in the country (Adebayo, 2013). Furthermore, Adebayo (2013) opined that, in order to survive, the unemployed youths may be living outside the law when they become desperate. This informs how unemployed youths can be available to be used thereby creating a state of insecurity in the country. Other scholars also attributed the use of youths in the Boko Haram attacks in the Northern part of the country to unemployed youths.

Given more understanding, Scheffran, Brzoska, Brauch, Link, \& Schilling (2012) argues that the rise of unemployed youths and their coming together would be worse if the issue of unemployment is not addressed. Many people who are unemployed are equally affected by psychological trauma which may create room for living outside the laws of the land. They could take laws into their hands. Agbiboa (2013) in his work on why Boko Haram exists, explained that backwardness in the northern part of the country, rising numbers of unemployed graduates, as well as massive numbers of unemployed youths among others, are the endangering issues surrounding why Boko Haram exists and their attacks continue in Nigeria. Onuoha (2010) expressed that, Boko Haram members are mainly drawn from those who are disaffected as well as unemployed graduates who are equally available to be used by them. Anyadike (2013) also opined that the membership of Boko Haram is drawn from unemployed university graduates, school drop-outs, as well as women and children.

Other factors responsible for violent conflicts in Nigeria include poverty, ethnic segregation, and religious intolerance as well as geographical divides (Anyadike, 2013). Forest (2012) connotes that, illiteracy and unemployment are more prevalent in the northern part of the country. That gives rise to the usage of youths by the Boko Haram in fighting against the Nigerian State. Agbiboa (2014) viewed that, the northern part of the country where Boko Haram operates is the most underdeveloped part of Nigeria. In his work, the youths and university graduates suffer from chronic unemployment. That opined why Boko Haram finds her membership from the category of the unemployed graduates and whose living in poverty domiciled environs. Uzodike \& Maiangwa (2012) argues that increasing rates of unemployment in Nigeria and high rates of poverty in the country's northern part poses threat to security.

According to the work of Ayegba (2015), Nigeria is a fertile ground for militant and insurgent activities such as Boko Haram considering the high rates of unemployment, poverty, increasing illiteracy challenges in the country. Rogers (2012) the rate of unemployment in Nigeria is higher in the northern part of the country than in the southern 
part. The further assertion of the work says that the ages between 18-25 years are unemployed and are the mostly affected.

\subsection{The Frustration-Aggression Theory}

The assumptions and principles of frustration-aggression theory evolve the fact that men rebel against the state when they consider their issues unaddressed and unattended to. The people are frustrated due to the fact that their issues regarding socio-economic and political challenges are not addressed. Hence, such frustrations could lead to aggression due to the fact that their challenges are not resolved and the failure of the government to solve the problems may lead them to the aggressive tendency. This research work also employed the frustration-aggression theory to explain why the youths get involved in the activities of the Boko Haram insurgents in Nigeria. In search for answers why the youths engage in violent attacks in the Nigerian polity, scholars such as Maiangwa, Uzodike, Whetho, and Onapajo (2012) cited the work of Dallard, Miller, Doob and Mowrer (1939) on frustration and aggression as well as Gurr (1970) on why men rebel in explaining the Boko Haram series of attacks against the Nigerian State.

In view of the above, Agbiboa (2013) in his work on why the Boko Haram exists argues on two fundamental issues between what the people want as well as what they get, between the ought to be and what is on the ground. The work further explained issues such as poverty, unemployment, and illiteracy as factors that bedeviled the NorthEastern part of the country where attacks by the Boko Haram are mostly carried out in Nigeria. Agbiboa (2013) cited the work of Gurr (1970) asserting that within an entity, people become dissatisfied when there is a feeling of being neglected and not having what they ought to get.

This work employed the frustration-aggression to explain Boko Haram violent attacks in Nigeria. The work, therefore, unveils the issues that propel Boko Haram members to engage to a series of attacks against the government of Nigeria. Maiangwa, Uzodike, Whetho and Onapajo (2012) in their work on Boko Haram and the reign of terror in Nigeria examined the dimension of state failure in relation to addressing socioeconomic challenges that bedeviled the country. These issues such as unemployment, poverty and illiteracy further serve as a threat to national security of Nigeria.

\section{Research Method}

The work made use of qualitative research design through the conduct of interviews. The work also made use of other sources such as journal publications and internet sources. Those interviewed were mostly from the academics and a research assistant was also employed.

\subsection{Methodological Choice}

This research work made use of the qualitative method for the purpose of gathering and interpreting data. The choice of choosing the qualitative method is to enhance in-depth knowledge on the subject matter. The qualitative research design is a method of research which is carried out through a procedure that produces results in words rather than statistics (Bello, 2007). Such research is also based on behaviour, people's lives functioning of the organization as well as a cultural phenomenon (Strauss and Corbin, 1998). The choice of a qualitative method in this research is also to give each participant the avenue to respond to questions in his/her own words. The method relates to the nature of the research problem which is appropriate for investigation in regards to the unemployment problem in Nigeria as a socio-economic challenge which serves as a security threat to Nigeria. The unemployment question in Nigeria creates issues such as Psychological Trauma, as such, those affected may become available to be used in the NigerDelta as Militants and Boko Haram Conflict in Nigeria

\subsection{Research Design}

In conducting a research, Merriam (2009) notes that research design involves strategy, plan and the structure of conducting a research project for the purpose of a specific study. More so, Collins (2004) suggest that design is developed as a means of carrying out formative research to test or refine knowledge based on modalities derived from previous research. Creswell (2008) opined four proposals for research design, these are epistemology, the theoretical stance, methodology and procedure. 


\subsection{Sampling Strategy}

According to Creswell (1998) a minimum of five (5) and maximum of twenty-five (25) respondents are used in a qualitative research and when it reaches a point of saturation, the researcher can stop from there. This research work, therefore, made use of a total number of ten (10) respondents from academics and the graduates who are unemployed were interviewed and we stopped at ten respondents due to the fact that the work reached a point of saturation where there was nothing new from the respondents in contributing to knowledge.

This research work, therefore, made use of purposive research sampling. The work of Sekaran and Bougie (2013) purposive sampling curtails the generalizability of the findings as obtains in probability sampling. This is in view of the fact that only a sample of highly knowledgeable experts in such fields or areas that are required to be interviewed for the purpose of gathering data for the conduct of the research. The purposive sampling design is a type of non-probability sampling which entails seeking and gaining access to individuals with the requisite wherewithal and expertise in terms of the experience, knowledge and the information that would be very useful in answering some of the research questions regarding the conduct of the study (Tongco, 2007).

3.4 Data Collection: The work made use of qualitative research which involves the use of primary and secondary sources of data collection. The uses of the primary source of data are oral, semi-structured and unstructured. The secondary data collection comprised of library sources, Newspapers, documents, briefings, journals, articles, internet, memoranda, round table discussion papers, textbooks, and gazettes among others.

\subsection{Data Analysis Technique:}

This research work, therefore, employed historical and interpretative method of discourse analysis with the available research materials and transcription of data sources for reliability and to have a deeper understanding of this research work. The issue of zoning or the rotational presidency in Nigeria has a historical background which it was designed to solve the problems relating to religion, ethnicity and geopolitical arrangement in the governance of the Nigerian State (Akinboye and Anifowose, 2008; Ayantayo, 2009). In addressing these issues as it relates to the worsening Boko Haram threat to national security, this work gives a deeper understanding using the historical analysis.

\section{Findings and Discussions}

\subsection{Poverty and Unemployment}

It was found that poverty and unemployment are the major issues affecting the youths and Nigerian graduates. Okoye (2017) agrees that the Nigerian state is faced with crises of unemployed graduates and it increases societal poverty. Lekobane and Seleka (2017) views a high rate of unemployment as a contributor to poverty in the rural areas employment opportunities are regarded as limited. Langer, Godefroidt and Meuleman (2017) in their work revealed that the Boko Haram recruits mostly those who are unemployed graduates, school drop-outs, and youths who may have not attended school. Onapajo (2017) argues that widespread poverty, illiteracy and unemployment are seen to be a socio-economic phenomenon which serves as a threat to Nigeria's security.

The issue of unemployment as viewed in the work of Odoh (2017) asserts that as the number of people who are unemployed continues to grow there are people who are prepared either to kill or be killed. More so, Adamu (2017) suggest that due to factors such as unemployment and social inequality in Nigeria, the Boko Haram has been able to recruit unemployed youths who are graduates from varies institutions of learning and the street children known as almajiri as their foot soldiers.

Chiazor and Udume (2017) view the groups in Nigeria such as Boko Haram, Niger Delta militants, Movement for the Actualization of Sovereign State of Biafra, and the Oduduwa People's Congress whose members are mostly the youths. Such groups are made up of unemployed youths who serve as a threat to Nigeria's security. Agbiboa (2013) in his work cited Gurr (1970) who argues that when the people rebel when they become dissatisfied with the government on a notion that they have less than what they ought to get. Issues that may affect the people over a period of time, if not addressed, such dissatisfaction by the people leads to frustration which in turn, the people would rebel against the government or the perceived source of their grievances (Agbiboa, 2013). The work of Gurr (2005) argues that inequality and poverty breed fertile grounds for violent political movements in general and 
terrorism to be specific. Agbiboa (2013) further explained in his work on how the most socioeconomically deprived part of the Nigerian State is the Northern part where the Boko Haram insurgents largely operate.

Maiangwa, Uzodike, Whetho and Onapajo (2012) observed that nation-state exists in order to serve the people through the provision of political and economic goods to their people living within the entity. It is, therefore, the duty of the nation-states to address the issues that concern their citizenries. Rotberg (2003) assert that nation-states fail when they are thrown into violence and they become unable to protect their people. This could be through the provision of security as well as political and economic goods to their citizens. The work also notes that political and economic goods include security of the citizenries, employment opportunities, health care, infrastructures, education, a legal framework for maintaining law and order.

Anderson and Bushman (2002) connote that, issue that ought to be addressed that are not taken care of, becomes provocative which could result in frustration. Such frustrations could increase aggression against the frustration agent. Feierabend and Feierabend (1966) opined that constructive solutions to frustrating situations are available in a participant society where ideas on how to resolve identified problems are solved. In the light of the above, frustrating issues such as unemployment could be addressed as agreed by respondent A, he says:

There are many ways to go about it. I'm one of those who believes that the government has no business engaging in business. The government has no business doing business. What government does is to create a very good environment, an enabling environment for business to thrive. And there are many things they can do; power, infrastructure, the banking system should be able to provide credit. All it takes in some places is your business ideas, you approach a bank and get a loan and set up your business, so the access to credit facilities has to be there. Then the government can also encourage through its regulatory agencies, quick steps in creating employment.

The respondent A, further opined that:

Yes, I don't think we have enough motor mechanics, this is my take, I don't think we have enough carpenters, we think we do but we don't, I don't think we have enough masons, and a lot of young people want to be trained in these skills. So that is one thing. If we are focused, we want a situation where we will create employers more than employees; it can be a policy of the government that we should critically pursue. The problem is that we have policies supporting this but the implementation is the challenge here.

More so, respondent A, expressed on using the political will in handing the issues:

The political will is the challenge here. Here is a good example; you see this cattle herdsmen conflict. Now once you do go into ranching as the world has done- the best business practice now is ranching - you get fatter cows, yes then you get people who supply grass to these cows. You create a value chain. So you see the grass that you think is worthless becomes money, then the cow produces milk, you don't need to be importing. The cost of milk will go down; the people supplying electricity to the ranches will make money. So you create a full value chain then you have beef that has very good quality because they don't roam around with those cows so they get fatter. You see a lot of countries have done that including Saudi Arabia which has the biggest ranch in the world including India. So you can see, creating employment is sitting down with stakeholders and coming out with a very workable plan, you take the people off the streets. And then our leaders need to stop short-changing young people. What makes you think the biggest thing a man can do is to be a thug? Yes, we discourage that, we have boys who are sent to go around and beat people up. Politicians do that, we should stop doing that. I don't think anybody will want his own son to be a thug and once we stop doing that, I think there will be changes $\left(24^{\text {th }}\right.$ March, 2017). 
In line with the issue of resolving the unemployment challenges which posed as frustration and may lead to youth's aggressiveness towards the Nigerian state, respondent B is of the opinion that:

We have only one major employer of labour in Nigeria which is the state. The number of youths thrown into the labour market every year is high and employment is limited. The Nigerian state and the economy is capitalist in principle, it is driven by the capitalist ideology where the private is supposed to be assumed to be the major actor, meaning that the responsibility of producing and distributing material needs of society are in the hands of the capitalists, which Nigeria in principle is. However, Nigerian private sector is not developed; we have an underdeveloped sector, for instance: how many industries in Benue are employers of labour? The private sector is not developed because Nigeria is not industrialized, that is why we are import dependent, if we are not producing then we have idle labour, Nigeria has employment problem for the reasons above. Another point for addressing the unemployment issue is that banning importation will help create labour for the farmer. This helps to swell the income for the farmers. Again, are technologically driven? This market can be opened up probably having assembly plants in terms of cars, phones, and laptops (23 ${ }^{\text {rd }}$ March, 2017).

On another view, respondent $\mathrm{C}$, opined that:

The issue of unemployment is not something that can be addressed in one day because it's taken a long time to develop. You see the Nigerian economy was so dependent on oil to the extent that some people became lazy and couldn't even want to be employed in other sectors of the economy, they became vendors, and they became people who were just doing something from that oil sector.

Regarding the issue on how to address the unemployment problem in Nigeria, respondent $\mathrm{C}$, further asserts that:

So, to address the unemployment situation in Nigeria, the government had to start from the diversification of economy and that is what the present government is attempting at doing, people will have to be employed in the line of agriculture and then there will be more industries set up to employ not only the government can be employing the teaming unemployed population, if the economy is diversified, and there are other sectors that can employ particularly the private sector, then the problem will be addressed but that will come gradually, it will not be a short-term solution. It has to take a while for the economy to take its roots, agriculture to be promoted, and then industrialization to curve up, so in a way that will help the situation (24 ${ }^{\text {th }}$ March, 2017).

Gurr (2015) posits that non-rational responses to frustration promote aggressive behavior and it is noted that men are inherently aggressive or can become aggressive when their goals are not achieved and they are frustrated. MuroRuiz (2002) revealed that people are generally driven to wage war against others when their goals are not achieved and they are frustrated. Kruglanski and Fishman (2006) assert that due to factors such as poverty, unemployment, low social status, political oppression which are frustrating issues in the lives of the people, such frustration could lead others in the search for alternative means.

The alternative means could be that others may join terrorist groups against the perceived frustrating agent. Okoye (2017) explained that the rate of unemployed graduates in Nigeria has formed part of the crises driven. Lekobane and Seleka (2017) revealed that high unemployment promotes and leads to an increase in poverty. Ghani (2017) is on the opinion that the situation of unemployed youth in the urban areas is considered pathetic.

The work of Adeyanju (2017) further concurred that those other issues such as regional conflict and ethno-religious crisis are aggravated due to the high rate of unemployed youths in Nigeria. As such, poverty and unemployment must be addressed to resolve the frustrating challenge facing the youths (Terwase, Abdul-Talib, Zengeni, \& 
Terwase, 2015; Yerima, Ibrahim, Terwase, \& Abdul-Talib, 2016). When the people are frustrated due to unemployment, then tend to be aggressive and they become available to be used by the militants and insurgent groups in order to fight the government.

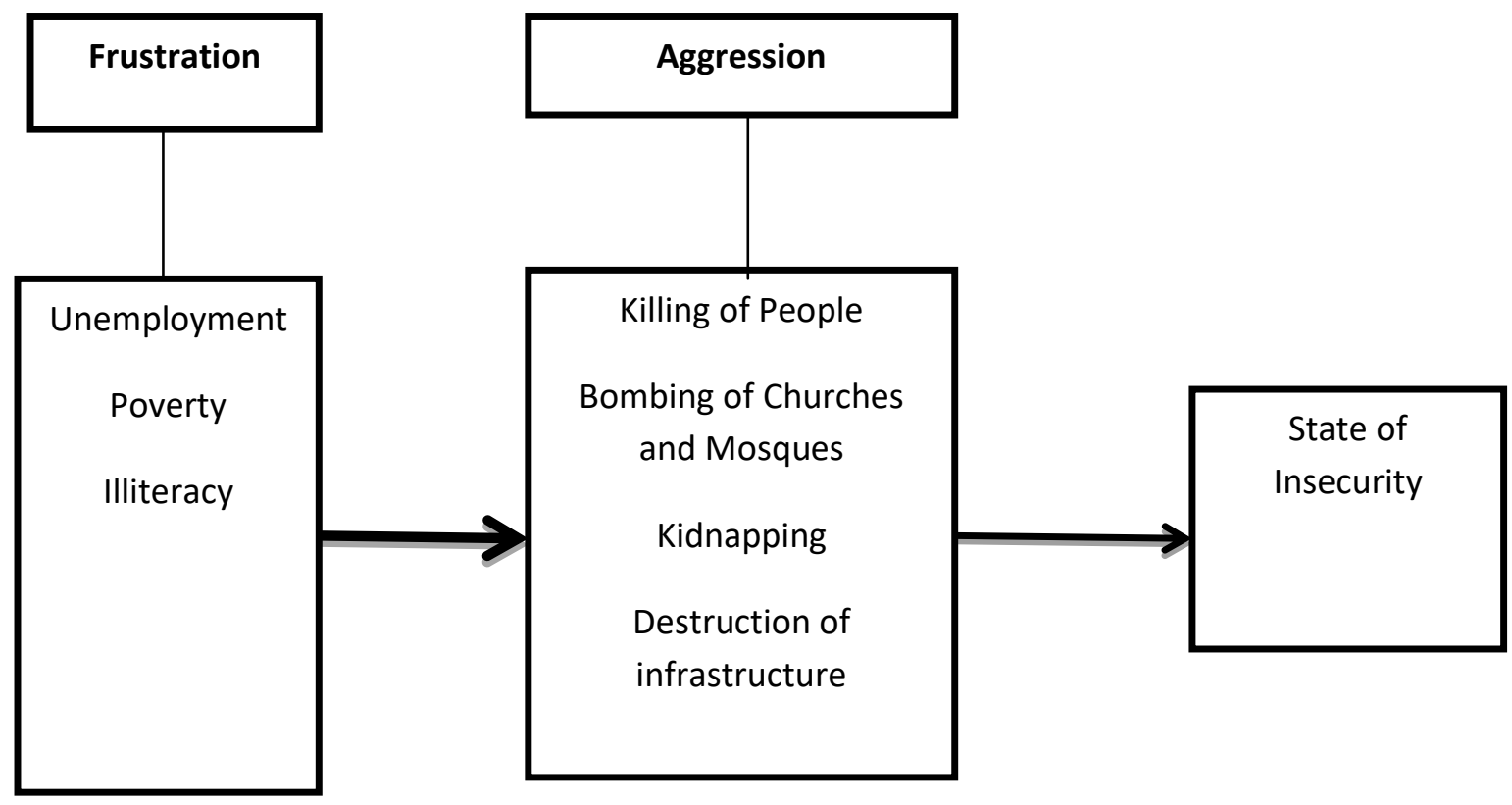

Figure 1.1 Theoretical framework diagram of the Frustration-Aggression Theory.

\subsubsection{A Proposed Framework on Private-Public Partnership on Job Creation in Nigeria}

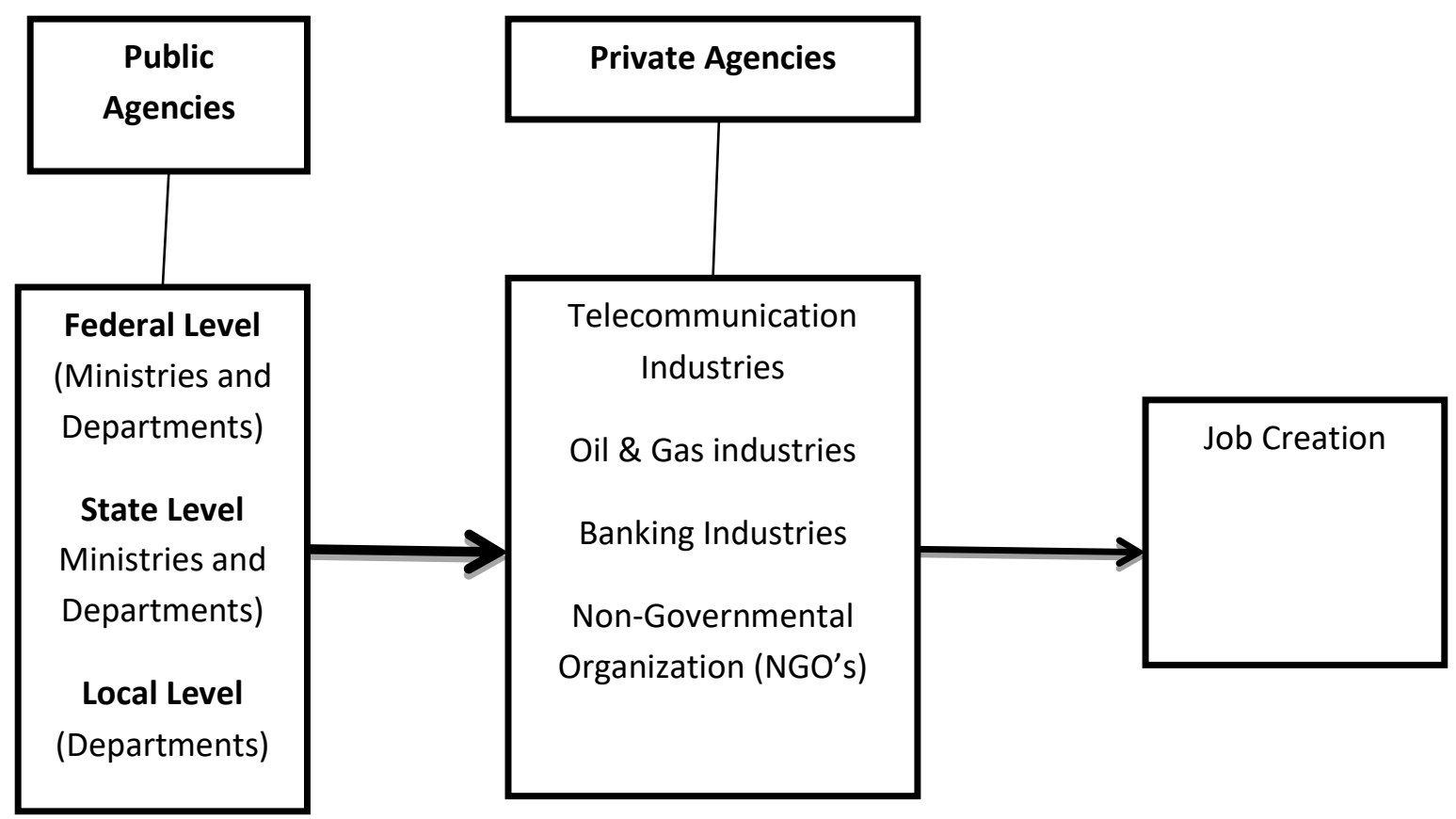

Figure 1.2 Proposed Framework on Public-Private Partnership on Job Creation in Nigeria 


\subsection{Public-Private Partnership on Job Creation in Nigeria}

There is a great need to put in place mechanism to boost job creation in Nigeria at all levels with specific attention to States and Local Government Areas. The Federal Government should engineer this strategy by making laws at the federal level where public-private partnership becomes necessary from the federal to local government level. There are many companies and organizations in Nigeria that needs to go into partnership with the government for the sole purpose of creating job opportunities for millions of Nigerians seeking for a job. Morel, Acharya, Broun, Dangi, Elias, Ganguly \& Hotez, (2005) assert that a public-private partnership should be sustained at the local level. In view of this fact, philanthropists, government agencies and the private sectors should partner together for the purpose of creating more jobs for the youths and the Nigerian university graduates in order to reduce the high rates of unemployed Nigerians.

This paper further suggests that the country is blessed with numerous raw materials for industries which are basically not utilized. The agricultural sector in Nigeria alone produces a lot of raw materials which are not turned into finished goods. They are wasting especially in states such as Benue, Taraba, Nasarawa, Plateau, and Niger. Example, Benue State is known as the food basket of the nation, the state produces the highest number of food products which are not adequately utilized. Okwu \& Daudu (2011) refers to the Benue State of Nigeria as the "nation's food basket" yet known to be as one of the poorest states. Benue State is endowed with vast land which is good for agricultural production. More so, the state produces agricultural products such as yams, tomatoes, rice, cassava, beans, soya beans, maize, millet, sorghum, and a lot of fruits such as oranges, mangoes, bananas (Oboh \& Kushwaha, 2009). But the big question is: why are there no industries in Benue State? There is an urgent need for the establishment of industries not just in Benue State alone but across the Federation of Nigeria. The unemployment rate has increased from 6.4 percent in January, 2015 to 18.8 percent by July, 2017, as seen in figure 4.2.1 below.

\subsubsection{An empirical data on the unemployment rate in Nigeria}

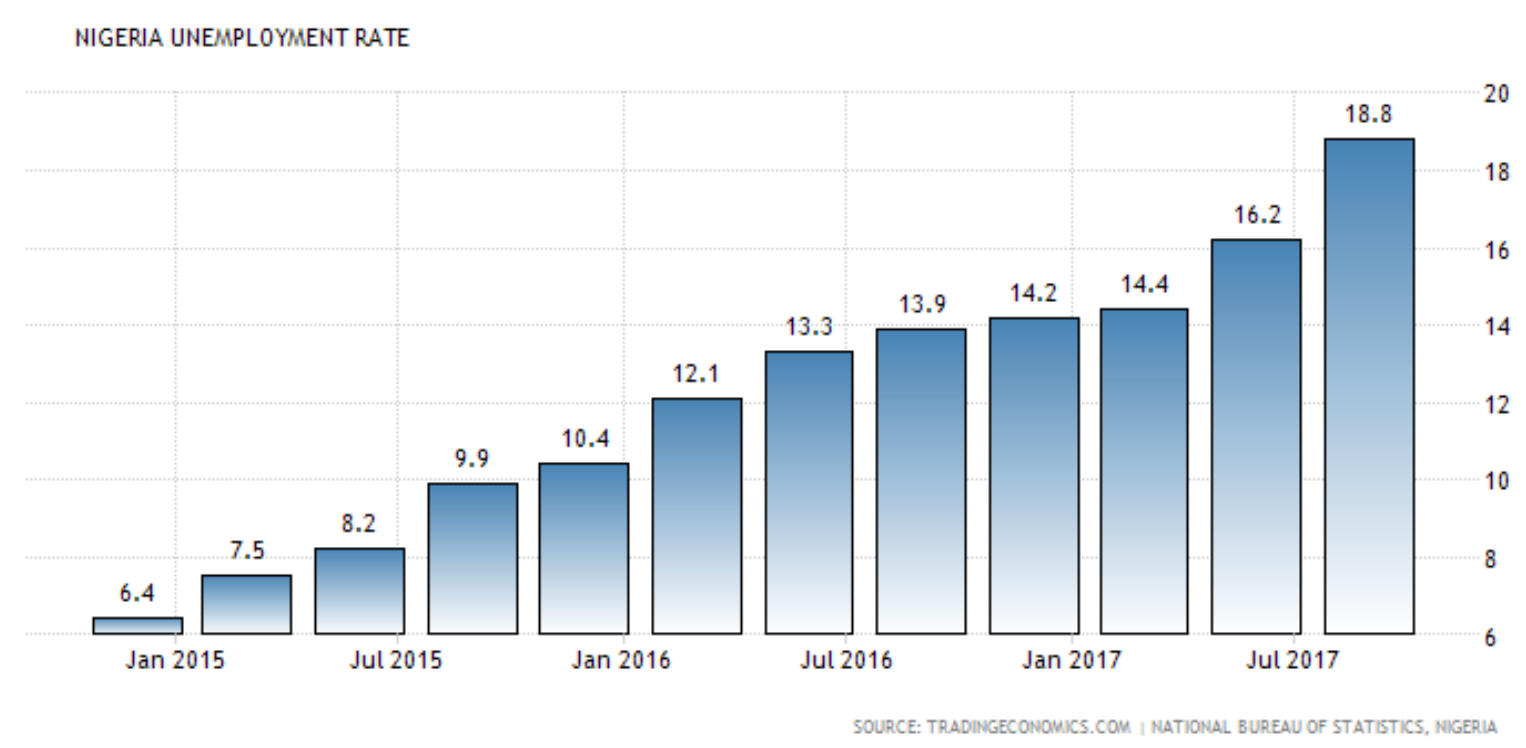

Source: Trading Economics cited National Bureau of Statistics, Nigeria (2018).

The public-private partnership gives room for partnership across all levels from the federal to local government level. Adegbite, Ilori, Irefin, Abereijo, \& Aderemi (2007) opined that the establishment of industries in Nigeria would promote job creation in the country where youths and graduates can be employed. That will reduce drastically the high rate of unemployment in the country. Maina (2014) connotes that, the big firms use a lot of raw materials for the production of finished goods. These firms, therefore, create job opportunities for those who are unemployed. This dimension showcases the fact that, such firms can equally make a contribution to entrepreneurial development. Terwase, Abdul-Talib, Zengeni \& Terwase (2015) explained that unemployment affects the psychological well- 
being of any given society. Any unemployed youth can be affected psychologically, thus, the need and the political will to address societal problems informs good governance.

Terwase, Abdul-Talib, Zengeni \& Terwase (2015) argues that the government's role in partnering with the private sector could promote job creation as well as the development of rural communities in Nigeria. These partnerships can be between the government and the oil and gas sector of the economy, the government and the banking industries, the government and the telecommunication sector of the economy as well as the government and the nongovernmental organization. Their work further asserts that job creation in the rural areas could reduce the ruralurban migration. Most of Nigeria's resources are based in the rural areas of the country. Agricultural produce is mostly produced in the rural areas but consumed in urban areas. Even the Nigeria's endowed natural resources are mostly found in the rural areas. These rural dwellers who are not educated refer to as illiterates even though given the opportunity, they could be educated. Nigeria needs to develop her rural environment as well while partnering with the private sector on job creation in order to employ both skill and unskilled labor.

\subsection{Partnership on Small and Medium Enterprises in Nigeria for Job Creation}

Onugu (2005) views the prospect of Small and Medium Enterprises (SMEs) in Nigeria in relation to Sole Proprietorship business, partnership business and business owned by the private sector economies. The role of SMEs in Nigeria cannot be neglected since they also contribute to the economy of the nation. SMEs create job opportunities for young and old Nigerians especially to those who owned them and to those who work under such SMEs sectors of the economy. This work thus, calls for the financing of the SMEs businesses in Nigeria for the purpose of creating more jobs for the millions of young Nigerians who are unemployed. Agwu \& Emeti (2014) outlined some of the major sources of SMEs which include: personal funding, funding from friends as well as family, and sourcing funding through partnership. The work further calls for government intervention in funding the SMEs so as to achieve the desired goals of its establishment.

Another dimension on SMEs is that of partnership with the Agricultural Development Bank which can lend money or credit facilities to farmers in the rural areas (Olaitan, 2006). Some farmers are into fishing, and some do engage in poultry farming which can equally provide job opportunities. Although, these form of business also needs capital for its establishment in Nigeria. As such, the quest for the financing of these SMEs is not only needed but adequate support should be rendered by the government of Nigeria through the Agricultural Development Bank. Etuk, Etuk \& Michael (2014) attribute government's role in promoting public-private partnership as another means of developing the SMEs so as to have friendly environment geared towards job creation in Nigeria. Oni \& Daniya (2012) further opined that the government and other financial institutions in Nigeria should be involved in the development of SMEs. There are many commercial banks in Nigeria that can finance SMEs. They can contribute to the financing of the SMEs in order for it to be strong and to further the creation of job opportunities in Nigeria. If all the youths are gainfully employed, that would reduce the rate of crime in the society, and more so, no availability of unemployed graduates who could easily be available for social vices such as militancy and insurgency.

\section{Conclusion}

In conclusion, this paper made use of the frustration-aggression theory in explaining the issues on why the youths engage in Boko Haram activities leading to attacks on the people and the government of Nigeria. The theory assisted in understanding the insecurity issues and how to tackle the security challenges that face Nigeria. The findings drawn from this research reveal that some of the youths who engage in terrorist attacks against the Nigerian state are unemployed while some are due to poverty and illiteracy. Their attack causes psychological trauma to the victims especially those whose relatives lost their lives as well as those who are internally displaced. The work, therefore, recommends a new public policy framework as a strategy in resolving the conflict in order to sustain peace and security in the country. The following recommendations are made to ameliorate the consequences of unemployment and under-employment in Nigeria;

Firstly, potential interventions could include career guidance and counseling at all levels of education, such as technical and vocational education, and also entrepreneurship education could be taught to young people. All these skills could be taught to brighten their chances of finding jobs in the labour markets. These could again lower rates of poverty thereby reducing tendencies for psychological consequences. A critical review of government policies related to solving the unemployment problem both in the present and in the future should be considered by the government itself and in collaboration with the private sector. 


\section{References}

[1]. Adamu, L. S. (2017). The Media's Role in Quelling Violent Conflict Involving Youths as Foot Soldiers: A Content Analysis of News Report on Boko Haram Suicide Bombers and Civilian Joint Task Force-CJTF. International Journal of Innovative Research and Development ISSN 2278-0211, 5(9)

[2]. Adebayo, A. A. (2013). Youths unemployment and crime in Nigeria: A nexus and implications for national development. International Journal of Sociology and Anthropology, 5(9), 350-357.

[3]. Adegbite, S. A., Ilori, M. O., Irefin, I. A., Abereijo, I. O., \& Aderemi, H. O. S. (2007). Evaluation of the impact of entrepreneurial characteristics on the performance of small scale manufacturing industries in Nigeria. Journal of Asia Entrepreneurship and sustainability, 3(1).

[4]. Adeyanju, J. O. (2017). The Gospel and the Impact of Poverty on the Practice of Ideal Christianity in Nigeria. International Journal, 2(2).

[5]. Agbiboa, D. E. (2014). Peace at Daggers Drawn? Boko Haram and the state of emergency in Nigeria. Studies in Conflict \& Terrorism, 37(1), 41-67.

[6]. Agbiboa, D. E. (2013) No Retreat, No Surrender: Understanding the Religious Terrorism of Boko Haram in Nigeria, African Study Monographs, 34 (2): 65-84

[7]. Agbiboa, D. E. (2013) Why Boko Haram Exists: The Relative Deprivation Perspective, African Conflict and Peacebuilding Review, Vol. 3, No. 1, pp. 144-157

[8]. Agwu, M. O., \& Emeti, C. I. (2014). Issues, challenges and prospects of small and medium scale enterprises (SMEs) in Port-Harcourt city. European Journal of Sustainable Development, 3(1), 101-114.

[9]. Aigbokhan, B. E. (1988); Planning, Employment and Income Distribution in Nigeria. Kristal Publications Ltd., Lagos.

[10]. Aiyedogbon, J. O., \& Ohwofasa, B. O. (2012). Poverty and youth Unemployment in Nigeria, 1987-2011. International Journal of Business and Social Science, 3(20).

[11]. Ajufo, B. I. (2013). Challenges of youth unemployment in Nigeria: Effective career guidance as a panacea. African Research Review, 7(1), 307-321.

[12]. Akinboye, S. O. and Anifowose, R. (2008) Nigerian Government and Politics, Elements of Politics, edited by Anifowose, R. \& Enemuo, F., Sam Iroanusi Publications, Lagos.

[13]. Alanana, O. O. (2003). Youth unemployment in Nigeria: some implications for the third Millenium. Global Journal of Social Sciences, 2(1), 21-26.

[14]. Anderson, C. A., \& Bushman, B. J. (2002). Human aggression. Annual review of psychology, 53(1), 27-51

[15]. Anyadike, N. O. (2013). Boko Haram and national security challenges in Nigeria; causes and solutions. Journal of Economics and Sustainable Development, 4(5), 12-23.

[16]. Ayegba, U. S. (2015). Unemployment and poverty as sources and consequence of insecurity in Nigeria: The Boko Haram insurgency revisited. African Journal of Political Science and International Relations, 9(3), 90-99.

[17]. Bello, A. B. E. (2007). Business research methods. Second edition. New York: Oxford university press.

[18]. Collins, A. (2007) Contemporary Security Studies, Oxford University Press Inc., New York

[19]. Collins, A., Diana, J. \& Katherine B. (2007). Design research: Theoretical and methodological issues. The Journal of the Learning Sciences, 13 (1), 15-42

[20]. Creswell, J.W. (2008). Research design: qualitative, quantitative and mixed methods approaches. Second edition, thousand Oaks, California: Sage publications.

[21]. Creswell, J. (1998) Qualitative Inquiry and Research Design: Choosing among Five Traditions, Thousand Oaks, CA: Sage.

[22]. Darity, W. A., \& Goldsmith, A. H. (1996). Social psychology, unemployment and macroeconomics. Journal of Economic Perspectives, 10(1), 121-140.

[23]. Diejomaoh, V. P., \& Orimalade, W. A. T. (1971). Unemployment in Nigeria: an economic analysis of scope, trends and policy issues. The Nigerian Journal of Economic and Social Studies, 13(2), 127-160.

[24]. Ghani, Z. A. (2017). A comparative study of urban crime between Malaysia and Nigeria. Journal of Urban Management.http://doi.org/10.1016/j.jum.2017.03.001

[25]. Godefroidt, A., Langer, A., \& Meuleman, B. (2017). Developing political trust in a developing country: the impact of institutional and cultural factors on political trust in Ghana. Democratization, 24(6), 906-928

[26]. Gurr, T. R. (2015). Why men rebel. Routledge.

[27]. Erikson, Erik H. (1959). "Identity and the Life Cycle, "Psychological Issues, January, 1, 50-100

[28]. Etuk, R. U., Etuk, G. R., \& Michael, B. (2014). Small and medium scale enterprises (SMEs) and Nigeria's economic development. Mediterranean Journal of Social Sciences, 5(7), 656.

[29]. Falae, S. O. (1971). Unemployment in Nigeria. The Nigerian Journal of Economic and Social Studies, 13(1), 59-75.

[30]. Feierabend, I. K., \& Feierabend, R. L. (1966). Aggressive behaviors within polities, 1948-1962: a cross-national study 1. Journal of Conflict Resolution, 10(3), 249-271

[31]. Forest, J. J. (2012). Confronting the terrorism of Boko Haram in Nigeria (No. JSOU-12-5). Joint special operations univ macdill afb fl. 
[32]. Ibeanu, O. (2000). Oiling the friction: Environmental conflict management in the Niger Delta, Nigeria. Environmental change and security project report, 6(6), 19-32.

[33]. Ikelegbe, A. (2006). Beyond the threshold of civil struggle: youth militancy and the militarization of the resource conflicts in the Niger Delta region of Nigeria.

[34]. Kruglanski, A. W., \& Fishman, S. (2006). The psychology of terrorism:"Syndrome" versus "tool" perspectives. Terrorism and Political Violence, 18(2), 193-215.

[35]. Langer, A., Godefroidt, A., \& Meuleman, B. (2017). Killing people, dividing a nation? Analyzing student perceptions of the Boko Haram crisis in Nigeria. Studies in Conflict \& Terrorism, 40(5), 419-438.

[36]. Lekobane, K. R., \& Seleka, T. B. (2017). Determinants of Household Welfare and Poverty in Botswana, 2002/2003 and 2009/2010. Journal of Poverty, 21(1), 42-60

[37]. Maiangwa, B., Uzodike, U. O., Whetho, A., \& Onapajo, H. (2012). " Baptism by fire": Boko Haram and the reign of terror in Nigeria. Africa Today, 59(2), 40-57.

[38]. Maina, S. (2014). The role of entrepreneurship education on job creation among youths in Nigeria. International Letters of Social and Humanistic Sciences, 4, 87-96.

[39]. McCann, L., \& Pearlman, L. A. (2015). Psychological trauma and adult survivor theory: Therapy and transformation. Routledge.

[40]. Merriam, S. B. (2009). Qualitative research: A guide to design and implementation. San Francisco: Jossey-Bass

[41]. Morel, C. M., Acharya, T., Broun, D., Dangi, A., Elias, C., Ganguly, N. K., \& Hotez, P. J. (2005). Health innovation networks to help developing countries address neglected diseases. Science, 309(5733), 401-404.

[42]. Muro-Ruiz, D. (2002). The logic of violence. Politics, 22(2), 109-117.

[43]. Obadan, M. I., \& Odusola, A. F. (2000). Productivity and unemployment in Nigeria. In the proceedings of the Ninth Annual Conference of the Zonal Research Units on productivity and capacity in Nigeria, Central Bank of Nigeria, Abuja.

[44]. Oboh, V. U., \& Kushwaha, S. (2009). Socio-economic determinants of farmers' loan size in Benue State, Nigeria. Journal of applied sciences research, 5(4), 354-358.

[45]. Odoh, O. E. (2017). Islamic Fundamentalism and National Security in Nigeria: Analysis of Boko Haram, 2009-2014 (Doctoral dissertation).

[46]. Okafor, E. E. (2011). Youth unemployment and implications for stability of democracy in Nigeria. Journal of sustainable Development in Africa, 13(1), 358-373.

[47]. Okoye, A. C. (2017). Entrepreneurship Education: A Panacea for Graduate Unemployment in Nigeria. Online journal of arts, management \& social sciences, 2(1)

[48]. Okwu, O. J., \& Daudu, S. (2011). Extension communication channels usage and preference by farmers in Benue State, Nigeria. Journal of Agricultural Extension and Rural Development, 3(5), 88-94.

[49]. Olaitan, M. A. (2006). Finance for small and medium enterprises: Nigeria's agricultural credit guarantee scheme fund. Journal of international farm management, 3(2), 30-38.

[50]. Omofonmwan, S. I., \& Odia, L. O. (2009). Oil exploitation and conflict in the Niger-Delta region of Nigeria. Journal of Human Ecology, 26(1), 25-30.

[51]. Omotola, J.S. (2008); -Combating Poverty for Sustainable Human Development in Nigeria: The Continuing Strugglell. Journal of Poverty, 12(4), 496-517.

[52]. Onapajo, H. (2017). Has Nigeria Defeated Boko Haram? An Appraisal of the Counter-Terrorism Approach under the Buhari Administration. Strategic Analysis, 41(1), 61-73.

[53]. Oni, E. O., \& Daniya, A. A. (2012). Development of small and medium scale enterprises: The role of government and other financial institutions. Arabian Journal of Business and Management Review, 1(7), 16-29.

[54]. Onugu, B. A. N. (2005). Small and medium enterprises (SMEs) in Nigeria: Problems and prospects. St. Clements University, Nigeria (Unpublished Dissertation for a Doctor of Philosophy in Management Award).

[55]. Onuoha, F. C. (2010). The Islamist challenge: Nigeria's Boko Haram crisis explained. African Security Review, 19(2), 54-67.

[56]. Oviawe, J. I. (2010). Repositioning Nigerian youths for economic empowerment through entrepreneurship education. European Journal of Educational Studies, 2(2), 113-118.

[57]. Oyefusi, A. (2008). Oil and the probability of rebel participation among youths in the Niger Delta of Nigeria. Journal of Peace Research, 45(4), 539-555.

[58]. Rogers, P. (2012). Nigeria: The generic context of the Boko Haram violence. Monthly Global Security Briefing, 1-5.

[59]. Salami, C.G.E. (2011); - Enterpreneurship and Youth Unemployment in Nigeria: The Missing Link. Global Journal of Management and Business Research, Volume 11 Issue 5 Version 1.0, April.

[60]. Salawu, B. (2010). Ethno-religious conflicts in Nigeria: Causal analysis and proposals for new management strategies. European journal of social sciences, 13(3), 345-353.

[61]. Scheffran, J., Brzoska, M., Brauch, H. G., Link, P. M., \& Schilling, J. (Eds.). (2012). Climate change, human security and violent conflict: challenges for societal stability (Vol. 8). Springer Science \& Business Media.

[62]. Sekaran, U., \& Bougie, R. (2013). Research methods for business: A skill-building approach, [e-book].

[63]. Strauss, A., \& Corbin, J. (1998). Basic qualitative research: Techniques and procedures for developing grounded theory. London: Sage publication Inc. 
[64]. Terwase, I. T., Abdul-Talib, A. N., Zengeni, K. T., \& Terwase, J. M. (2015) Sustainable Behaviors: The Psychological Impact of Social Entrepreneurship on Tsambe Community in Nigeria. Journal of Governance \& Development, Vol. 11, Special Issue on Social Entrepreneurship,141-150

[65]. Terwase, I. T., Abdul-Talib, A. N., Zengeni, K. T., \& Terwase, J. M. (2015). The Psychological Trauma on Boko Haram Victims in Nigeria: Conflict Resolution Perspective. Mediterranean Journal of Social Sciences, 6(6 S4), 519.

[66]. Terwase, I. T., Abdul-Talib, A. N., \& Zengeni, K. T. (2015). Conflict resolution: The truncated zoning arrangement and the Buhari political tsunami in Nigeria. Jurnal Studi Pemerintahan: Journal of Government and Politics, 6(2).

[67]. Tongco, M. D. C. (2007). Purposive sampling as a tool for informant selection. Ethnobotany Research and Applications, 5, 147-158.

[68]. Trading Economics cited National Bureau of Statistics, Nigeria (2018). Retrieved from https://tradingeconomics.com/nigeria/unemployment-rate, on 30/09/2018.

[69]. Ukeje, C. (2001). Youths, violence and the collapse of public order in the Niger Delta of Nigeria. Africa Development/Afrique et Développement, 26(1/2), 337-366.

[70]. UNDP (2010). Human Development Report Nigeria 2008-2009. Achieving Growth with Equity.United Nations Development Programme.

[71]. Uzodike, U. O., \& Maiangwa, B. (2012). Boko Haram terrorism in Nigeria: Causal factors and central problematic. African Renaissance, 9(1), 91-118.

[72]. World Bank (1998); 1998 World Development Indicators, The World Bank, Washington, D. C.

[73]. Yerima, H. M., Ibrahim, M. B., Terwase, I. T., \& Abdul-Talib, A. N. (2016). Peace and conflict resolution: Biafra agitation and zoning of presidency in Nigeria. Peace and Conflict, 6(2). 